Article

\title{
Local Governance and Labor Organizations on Artisanal Gold Mining Sites in Burkina Faso
}

\author{
Lala Safiatou Ouedraogo * and Patrick Mundler
}

Faculty of Agriculture and Food Sciences, Department of Agri-Food Economics and Consumer Sciences, Université Laval, Pavillon Paul-Comtois, 2425 Rue de l'Agriculture, QC G1V 0A6, Canada; patrick.mundler@fsaa.ulaval.ca

* Correspondence: lala.ouedraogo.1@ulaval.ca; Tel.: +1-418-254-7298

Received: 5 November 2018; Accepted: 9 January 2019; Published: 24 January 2019

\begin{abstract}
This paper based on the institutional analysis and development framework (IAD) is to discuss the local governance and labor organizations on artisanal gold mining camps in Burkina Faso; a West African country that in recent years has been increasingly exploiting its gold reserves. Field data were collected from three sites in the villages of Diosso, Siguinoguin and Zincko in accordance with the purposive sampling. One major finding gleaned from the on-site research is that forms of governance vary along a continuum from flexible (enforced by a joint powers: artisanal miners' union, customary authorities and landowners) to rigid (enforced by landowner). Another finding is that the type of relationship between indigenous communities and miners depend on the importance of the authocthony of the artisanal miners. Indeed, they are harmonious in Zincko, where miners originate from the village, whereas they are tense in Siguinoguin, which is populated by migrants. Eventually, this paper relies on the French school of proximity to enrich the definitions given to the attributes of the physical world and the attributes of the community highlighted by Ostrom's theory as geographical proximity fails to detail forms of relational proximity that clearly structure the way governance is organized on the mining camps.
\end{abstract}

Keywords: community-based management; common-pool resource; artisanal gold mining; institutional analysis development framework

\section{Introduction}

Artisanal mining has become a growing phenomenon in many developing countries [1-3], which raises the question of why the communities that spring up around mine sites often manage to work together over time. It is tempting to view small-scale mines as disorganized sites prone to collapse. Nevertheless, the number of people throughout the world involved in artisanal mining has increased dramatically from an estimated six million in 1992 to 13 million in 1996 [4]. In 2009, it was estimated that more than 100 million people worldwide depend directly or indirectly on artisanal and small-scale mining for their livelihoods [5]. In Africa, it is estimated that between 6 million and 8 million people are directly employed in the sector, with an estimated 20 million depending on the sector [5].

Throughout the world, literature informs us that miners are rather self-organized despite the informal and illegal aspect and the apparent chaos that occurs on the mining sites: mud houses settled haphazardly, bars and mining pits just next to one another, ongoing deafening sounds from artisanal miners that continually dig and crush ore mines even in houses [6-8]. In this paper, we consider that there is an actual mining community. According to Werthmann [9] (p. 129), "sojourners of mining camps share a common knowledge about a set of regulations of cohabitation and cooperation in a mining, regardless of whether they are actually staying there at a given moment...it is a community that temporarily aggregates in boom regions" making a translocal community. Adding to that is the 
fact that a mining "community can range in size from a city which could be serving as a base for distant 'fly in fly out' operations to a village (which relies extensively on local mining" [10] (p. 192).

Following these observations, one might be tempted to ask whether the same types of self-organizations occur in all mining sites and what determines which specific type of governance (rules, actors...) is at stake on a specific mining site. The present study seeks to explore these questions related to how governance is organized on artisanal mines. To do so, we carried out field work at three artisanal gold mining sites in Burkina Faso (for comparison purposes), a landlocked West African country where significant gold reserves have been discovered. In 2009, gold became the country's main export commodity, overtaking cotton, which had been the dominant export since 1965.

Artisanal mining has become a major issue for many African countries. As workers previously engaged in agriculture turn to mining, there are fears that a permanent shift in the labor force is underway that could lead to problems of food scarcity [11-16]. In addition, there are growing concerns about the negative impacts or artisanal mining, such as the pollution it generates from the use of cyanide and mercury $[13,17,18]$, the social impacts of child labor, and work-related illnesses and accidents $[3,12,19,20]$.

To carry out our research, we used the institutional analysis and development (IAD) framework developed by Elinor Ostrom in the 1980s. The framework suggests that natural or artificial resources can be managed by local communities rather than the state or private actors without necessarily leading to a "tragedy of the common" as described by Hardin [21]. Under such a scenario, the resource in question is referred to as a common-pool resource [22,23].

A great deal of research has shown that this framework can be applied to many types of resource settings. For instance, it has been used to evaluate forest management practices in different countries. The results of these studies found no statistically significant differences between government managed and community managed forests, thereby highlighting the key role played by local communities in managing their own resources [24,25]. The IAD framework has also been advocated as a useful tool for analyzing fisheries policies [26]. While the approach has been helpful for understanding community resource management, to our knowledge, it has never been used to evaluate the local governance of artisanal gold mining sites. Our study seeks to bridge this knowledge gap by using the IAD framework to determine the local governance and labour organizations that take place at artisanal mining sites. Understanding these dynamics is crucial given the current push by governments and non-governmental organizations towards a better regulated mining sector in order to control its negative effects [27].

The remainder of the paper is organized as follows: the first section discusses literature related to artisanal mining. The second section exposes the methodology of the study. The analytical framework will be analyzed in the third section while the results and the discussion will be respectively discussed in Sections 4 and 5 followed by the conclusions.

\section{Literature Review}

\subsection{Artisanal Mining}

There is considerable research on the topic of small-scale mining and the literature is organized around three key themes.

The first theme examines the reasons why people chose to pursue artisanal mining. As in the case of any alternative rural livelihood activity, the decision is determined by demand-pull factors or distress-push factors [15,28-30]. From a demand-pull perspective, people involved in agriculture who live above the subsistence level might chose to pursue artisanal mining since it promises potentially higher economic returns. On the other hand, distress-push factors would explain why people living in difficult financial situations would enter the sector. Besides these two categories, some scholars as Bryceson and Jønsson [31] and Hilson [32] have pointed out a category of small scale miners that engage in the activity as a career choice, hoping that it would provide him the necessary needs for their 
lives. Others like $[9,33]$ brought up another group of individuals that migrate to mining camps as they are fleeing social pressures such as unwilling marriages, banishment for incest, murder or witchcraft.

The second theme explores both the negative and positive effects of artisanal mining and tries to determine whether it is a sustainable economic activity. Small-scale mining generates pollution during the gold processing stage when mercury is released inadvertently into the environment $[17,18]$. It also raises a number of health and safety concerns. For instance, exposure to pollutants can cause disease and collapsing mine shafts often lead to injury or death $[12,13,34]$. Some of the negative social effects of small-scale mining include child labor, prostitution, violence, drugs, migration and tensions among large mining companies, artisanal miners, local communities and governments $[8,12,13,34]$. Nevertheless, research has also shown that artisanal mining can have many benefits. For instance, due to low entry barriers, it can help drive rural entrepreneurship by creating market opportunities for people: traders, local farmers, jewelers, etc. [11,17,33,35-37]. In addition, rural populations use the income earned from artisanal mining to pay for daily expenses while some local government officials and public institutions rely on it during challenging social conditions [13,16,38-41]. Small-scale mining can also help women become more financially autonomous since it gives them the opportunity to prospect for gold or to sell food, drinks and other materials to miners $[1,14,17,33,41-44]$.

The third theme analyzes the way artisanal mining communities are governed. While regulating the sector through license enforcement is seen as necessary, countries that have attempted to do so often fail to achieve results due to the complexity of procedures related to the license acquisition or the lack of knowledge of the sector's organizational setting [7,15,27,43,45]. Research has shown that artisanal mines are governed in one of three ways. The first is a system of regulation whereby the mine is run by a collective power (i.e., agreement among miners or an association led by a village chief) $[34,41,46]$. The association allocates plots to interested pit owners, resolves conflicts and may even collect taxes on behalf of the village chief and landowners. The second system involves an organization led by a site manager who is responsible for running the mining camp [8,47]. Even though Werthmann described a situtaion that occured before 2006 when mining sites were controlled by a state-owned gold marketing company known as "Comptoir Burkinabè des Métaux Précieux" where Ousmane played a role of intermediary among the comptoir, villagers and gold diggers, the work of Sangaré [48] proves that such management still exists on certain mining camps in Gbomblora in the Southern province of Poni. After negotiating with landowners and customary authorities, the manager assumes responsibility for the site and collects rent money from the various workers in the camp. Managers under this arrangement can sometimes earn monthly incomes as high as USD 9700 [8,47]. In the third system of regulation, authorized companies arranged ("comptoirs" among others) order on the mining camps with either the collaboration of former miners and private security officers $[46,49]$. Usually, prior to the establishment of the comptoir, the representatives of the comptoir would negotiate with customary authorities and local government officials (mayors, prefects). The former would ask for in-kind donations like cattle in order to make sacrifices (by earthpriests) that is believed to ensure miners' security and prosperity. The "comptoir" plays four different roles on the mining site. First, it manages the relation between miners and the indigenous communities (agreements on sacrifices, revenue sharing, land tenure arrangements and conflict resolution). Second, it is in charge of the relation between miners and the local government (administrative procedures such as reporting deaths, collecting tax on behalf of the municipality). Third, it organizes a system of pre-financing loans for miners that lack financial resources. Fourth, the company manages matters related to security and safety of workers on the mining sites. So far, the research conducted in the field shows that the artisanal mining sector is characterized by a great diversity of both miners and types of organization of mines. On the other hand, they provide little information concerning the formal and informal rules and standards governing the organization of work on mining sites, where we attempt to fill the gap. The added value for academics are various. First, we revealed the existence a continuum of governance ranging from a flexible form of governance to a rigid form of governance depending on the key player of the organizational setting. Second, we revealed that miners established some informal 
rules such as exclusion rules that were not previously discussed in the literature. Third, we have undertaken performance assessment based on informations provided by the miners (luck, financial means). Fourth, we have shown that poverty level closely depends on miners' job categories. As for development professionals or aid agencies, this study will help to identify public policy framework that would build capacity to meet the sector's need of sensitizing to mitigate health and safety, social and environmental issues.

\subsection{Mining in Burkina Faso}

The anthropological work on the gold extraction show that, contrary to the common thoughts, gold mining would have appeared in the Middle Ages in West Africa notably in Burkina, and Ivory Coast where gold trade was practiced in the trans-Saharan zone as well as in the Gulf of Guinea [50-52]. This technique of extracting precious metals using rudimentary techniques and tools such as pickaxes and dabas is labor-intensive and is often practiced under dangerous and illegal conditions $[1,17,53]$. In the precolonial period, especially in the eighteen century, the archeological remains indicated that gold was extracted and exchanged in the Mouhoun region occupied by the lobi tribe even though only Jula traders mined and exchanged the resource for other goods [37]. During the colonial period, French colonial power conducted some geological research. Later on, the West African Great Works company established an industrial mine in the region of Poura that produced $250 \mathrm{~kg}$ from 1930 to 1944 [54]. Gradually, the non-industrial gold extraction aroused a progressive interest in the 1980s when severe droughts hit the Northern part of Burkina Faso, creating a great famine and a lack of income for the populations concerned [3,9,11,36,50,55-57]. It will eventually spread to the Central and the Southern region in the 1990s. Facing the emergence of this new activity, the government of Thomas Sankara established the state-owned gold marketing company "Comptoir Burkinabé des Métaux Précieux" in 1986 (CBMP). The comptoir was acting as a monopoly in buying, processing and selling artisanal gold collected on artisanal and semi-industrial mines; and also as a provider of a secure environment for miners by establishing a spatial organization of the site: three different areas for gold extraction, processing, buying and selling [3]. Even though this government was able to control the quantity of gold produced and exchanged on the mining camps, a great quantity from $40 \%$ to $50 \%$ was smuggled out of the country. When Thomas Sankara was assassinated in 1987 , the new political regime of Blaise Compaore was more directed towards an openness to international trade. A few years later, in the 1990s, the World Bank and the International Monetary Fund imposed the liberalization and the privatization of the mining sector in Burkina Faso as well as other African countries $[12,58,59]$. Thus, Burkina Faso made a public statement about organizing its mining sector which ended up in the adoption of the country's first mining code in October 1997 and the emergence of private gold trading posts such as SOMIKA and Sav'or. It is important to note that, according to the mining code of the country, any gold located in the basement or the soil of the country is the property of the state; this is opposed to the free mining argument of countries similar to Canada where priority is given to mining activities at the expense of any other activities $[36,43,60]$. Then, following this liberalization, the competition faced by the CBMP eventually led to its bankruptcy and liquidation in 2005-2006 [3,55,56,61]. This is not surprising. In fact, as pointed out by Bossom and Varon [62] and Campbell [63], state intervention in the mining sector in most developing countries turns out to be inefficient because of the inappropriate budget, procedures and lack of experience in the sector. Despite the liberalization of the sector, one of the most striking events is that most of the artisanal gold produced in Burkina Faso is still being smuggled out of the country. In fact, a report conducted by Gueniat and White [64] found that the Togolese gold imported by Switzerland is in fact gold produced in artisanal mines of Burkina Faso knowing that Togo is officially a non-gold producer. This smuggle is organized by comptoirs such as SOMIKA owned by the wealthy businessman Adama Kindo that bought gold from artisanal miners, resold it to the Lebanese owned company Ammar group that transits the gold through Togo. In doing so, the Ammar group avoided paying a gold export tax in Burkina and rather paid in Togo where this tax is minimal. In 2003, a new mining code 
was enacted. The government tried to regulate the artisanal mining sector by creating some permits known as authorization for artisanal mining (AAM) $[3,46,56]$. The AAM is a two-year renewable permit that allows the owner to search for gold on a specific area-maximum of one kilometer square. Non-transferrable, the permits are only issued for Burkinabe nationals. Nevertheless, the goal of regulating the sector was not reached because the AAM was obtained through complex procedures for the majority of the miners who are illiterate. Eventually, AAM was acquired by wealthy entrepreneurs from the capital that coerced miners to sell their gold at a lower price compared to the market price. In May 2015, the parliament of the political transition "Conseil Natonal de la Transition" revised the 2003 mining code; however, it has yet to be implemented (Jeune Afrique, 2016). The major changes include the introduction of a tax for the "local mining development fund" that would support local communities affected by mining exploitation, removal of certain tax benefits and enhanced protection for the environment. In a nutshell, since the 1980s, we have seen an attempt from the government to regulate the non-industrial mining. At the beginning of this process, this attempt has been somewhat successful even though a great part of the gold production was being smuggled out of the country. However, in the last decade, a new way of regulating the sector enacted by the parliament has been keeping real artisanal miners out of the process for the benefit of wealthy entrepreneurs.

\section{Methodology of the Study}

\subsection{Attributes of the Physical World}

Fieldwork for the study was conducted in Burkina Faso, a West African country bordered by Mali, Niger, the Ivory Coast, Ghana, Togo and Benin (see Figure 1). For purposes of comparison, three artisanal mining camps were selected, each of which was located in different climate zones in order to represent the diverse background of the country climatically and spatially.

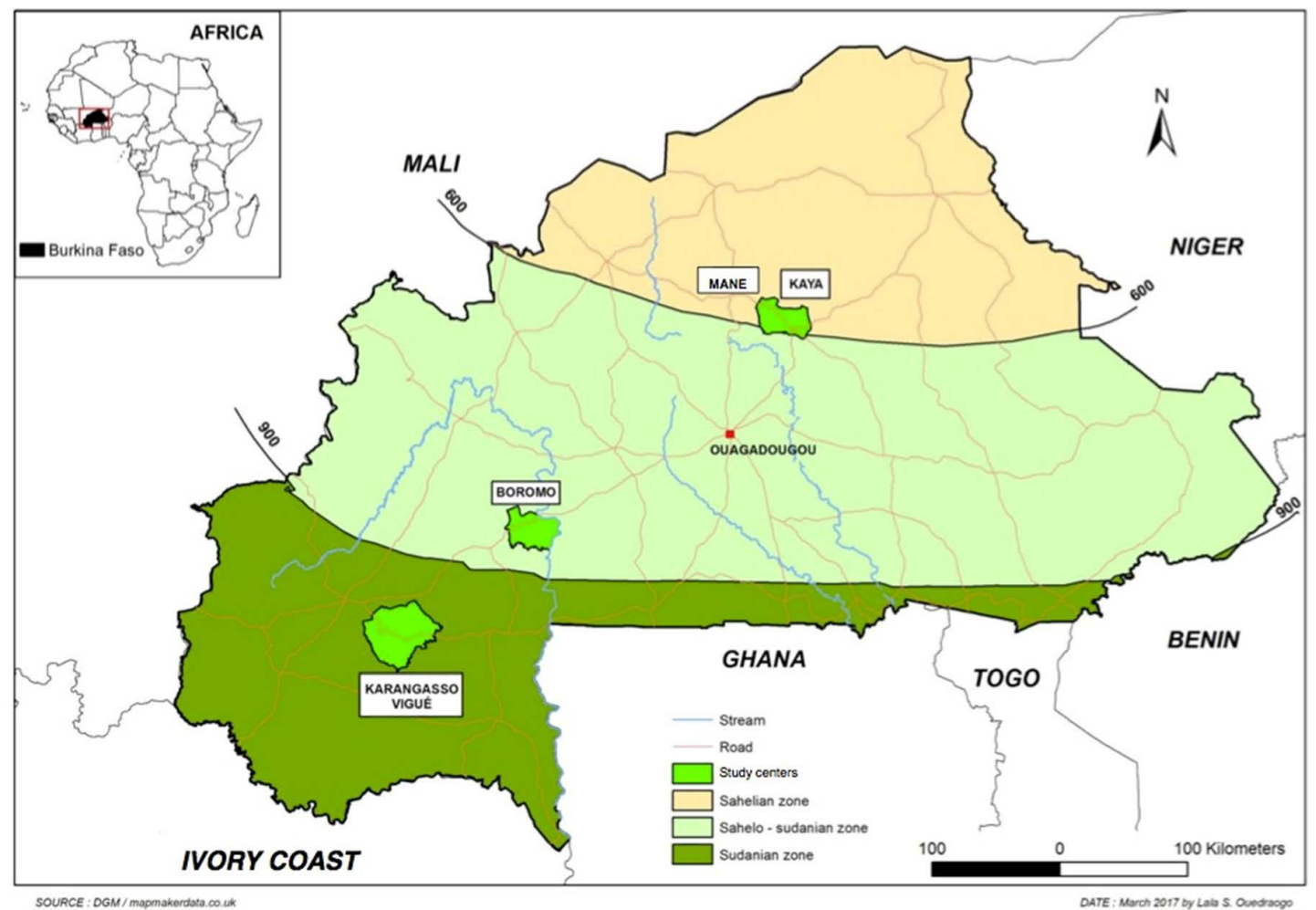

Figure 1. Location of the study areas.

Table 1 presents facts and figures on the study zones. Among them all, Diosso is the largest mining camp in terms of number of both pit holes and miners. 
Table 1. Data on the study zones.

\begin{tabular}{lllll}
\hline $\begin{array}{l}\text { Regions } \\
\text { (Province) }\end{array}$ & Commune & $\begin{array}{l}\text { Population (Number } \\
\text { of Villages) }\end{array}$ & $\begin{array}{l}\text { Creation of the } \\
\text { Mining Camp }\end{array}$ & $\begin{array}{l}\text { Number of Pits } \\
\text { (Miners) }\end{array}$ \\
\hline $\begin{array}{l}\text { Southwestern } \\
\text { (Houet) }\end{array}$ & $\begin{array}{l}\text { Karangasso } \\
\text { Vigue (Diosso) }\end{array}$ & $75,481(25)$ & 2006 & $\begin{array}{l}150-250 \\
(3000-5000)\end{array}$ \\
\hline $\begin{array}{l}\text { Boucle du } \\
\text { Mouhoun (Bale) }\end{array}$ & Boromo (Siguinoguin) & $29,845(8)$ & 2009 & $\begin{array}{l}100-150 \\
(500-750)\end{array}$ \\
\hline $\begin{array}{l}\text { North-Central } \\
\text { (Sanmatenga) }\end{array}$ & Mane (Zincko) & $46,484(44)$ & 1987 & $\begin{array}{l}100-150 \\
(500-750)\end{array}$ \\
\hline
\end{tabular}

\subsection{Objectives}

This research attempts to understand the governance of work organization in gold mining camps in Burkina Faso. By mobilizing the framework of the analysis of the IAD, our objective is to analyze how the common management of the resource plays on the productivity of the mines, the sustainability of their exploitation and the reduction of the poverty of the populations concerned.

\subsection{Analytical Framework}

Our paper posits two hypotheses based on the IAD framework developed by Ostrom [22].

1. Artisanal gold may be considered a common resource since it is both a rival and a non-excludable good [65]. Specifically, gold is a rival good because, when artisanal miners extract it from the ground, it is no longer available to others. Furthermore, it is difficult to exclude people from accessing it since gold can be illegally mined without authorization.

2. Artisanal gold mining communities can manage their gold resources without leading to a tragedy of commons as suggested by Hardin [21].

One might think that since gold is a non-renewable resource unlike land or water, mining populations are very mobile and develop no ties to land or local populations; hence, they do not set up any forms of a common governance. This is questionable for many reasons. First, according to the the definition of a common-pool resource, the resource may be a natural resource or any hand-made or artificial resource [22]. There is no indication that a common resource can only be a renewable natural resource. Second, mobility does not imply failure to organize, even if this organization is temporary. Third, asserting that miners are very mobile, and thus do not develop ties with land or local populations, is far too simplistic and does not comply with the cases reported in the literature. For example, in the case described by Werthmann [11] in the village of Dimouan in the Southwestern of Burkina Faso, unlike miners who leave the village in the rainy season for other mining camps, the others stay there and borrow some farmland from the villagers in exchange for money or part of the future harvest. Thus, a willingness to create ties with the land and population in which they are working clearly emerges. In addition, during our fieldwork, we have seen that some of the mining camps have been operating for more than 10 years. In the meantime, many miners have settled down with their wives and families and run other businesses. In such context, we do not have to overlook these ties.

Table 2 summarizes the main variables of the IAD framework. The centerpiece of this approach is the action arena where people interact through exchange of goods and services and conflict resolution. Its main components are participants, positions and outcomes. This arena is influenced by physical factors, the socio-economic status of actors and the working rules established by the participants. 
Table 2. Institutional Analysis and Development framework adapted from Ostrom [22].

\begin{tabular}{|c|c|}
\hline Attributes of the Context & Attribute Forms \\
\hline Attributes of the physical world & $\begin{array}{l}\text { Geographical area: map, spatial characteristics } \\
\text { Quantity: changes in resource levels over time }\end{array}$ \\
\hline Attributes of the community & $\begin{array}{l}\text { Socio-economic: age, household size, sex, education } \\
\text { Culture: ethnicity, cultural background }\end{array}$ \\
\hline $\begin{array}{l}\text { Action arena: analyse and } \\
\text { predict behaviors } \\
\text { within the organisatonal setting }\end{array}$ & $\begin{array}{l}\text { Actors: stakeholders in the mining sector } \\
\text { Action situation: defines the context in which } \\
\text { interactions occur among the different participants } \\
\text { Outcomes: observed results from interactions } \\
\text { among participants }\end{array}$ \\
\hline Working rules: formal/informal & $\begin{array}{l}\text { Boundary rules: physical limit of the resource } \\
\text { Position rules: change from one position to another } \\
\text { within the organizational setting } \\
\text { Scope rules: terms of use for the resource } \\
\text { Choice rules: monitoring procedures } \\
\text { Aggregation rules: permission and prevention } \\
\text { Information rules: shared and hidden information } \\
\text { Payoff rules: rules related to sanctions }\end{array}$ \\
\hline Performance assessment & $\begin{array}{l}\text { Productivity: assess performance using } \\
\text { productivity indicators } \\
\text { Sustainability: assess performance using sustainable } \\
\text { development indicators } \\
\text { Poverty reduction: assess performance in terms } \\
\text { of poverty reduction }\end{array}$ \\
\hline
\end{tabular}

\subsection{Data Collection}

Data for this study is obtained through in-depth interviews with miners and farmers as databases on variables like the informal rules established on the mining camps, the job categories, the roles of influential actors and the performance indicators of the governance outcomes of local mining sites are not available. Thus, fieldwork of four months (from January to April 2017) has been organized in Burkina Faso on the three mining sites with approximately 40 days on each artisanal mining camp. First, we meet with traditional rulers, artisanal miners association and land owners to get permission to conduct the survey. Afterwards, they selected people to assist for the first interviews. Thus, interviews were conducted on chain referrals (snowball technique) from the start. We also made sure to select participants after selected criteria (purposeful sampling technique) to prevent any discrimination based on gender, education, occupation, status, culture or ethnicity $[66,67]$. We roughly rounded up the sample size at 30-50 individuals per site as soon as we reach the saturation point. Overall, the sample consisted of 154 people of whom 123 were artisanal miners and 31 were farmers who lived near the camp sites (details on the sample will be discussed in the following section). Interviews were mainly conducted in Moore and Dioula, the two major languages of the country, and lasted between one and a half to two hours. It is also important to note that all the sites are acknowledged by the customary authorities (village chief and the other representatives), but none of the interviewees hold an authorization for artisanal mining during the interview. Each interviewee was asked to give information about their backgrounds and discuss various questions like why they are pursuing the activity, their role on the camp, and the socio-economic impacts of the activity, among others. This information has subsequently been reported on Microsoft Excel (14.7.3, Microsoft, Redmon, WA, USA) before being processed on Stata 12.1 (12.1, Statacorp, College Station, TX, USA) to retrieve descriptive statistics. 


\section{Results}

\subsection{Attributes of the Communities}

Within the sub-sample of 123 artisanal miners interviewed on the three mining camps (mining areas), 111 were male and 12 were female. Most respondents were also young adults likely because artisanal mining is labor-intensive and requires a great deal of physical strength as in Grãtz [68], Mégret [53], and Teschner [41]. The low number of female miners is common at mine camps. On one hand, they are not admitted in the mines [9]. On the other hand, women often find pit digging and the world of gold mining to be difficult, indicating that the activity is gender-oriented as addressed by the only female pit owner we have found while visiting the study areas and also explained in Kitula [13]. In Siguinoguin and Diosso, women instead set up depots where miners come to process their stones. However, in Zincko, female miners dig up to $50 \mathrm{~cm}$ into the ground next to the large pits and winnow gold ore using large plastic bowls. Previous studies have described similar practices [1,9,33,41].

Table 3 compares the socio-demographic characteristics of the respondents at each mining camp. At all three sites, the proportion of illiterate miners and farmers was high. This result, however, is not surprising, given that Burkina Faso suffers from a high illiteracy rate, which limits people's livelihood options. In addition, most of the miners interviewed at each camp site belonged to the Mossi tribe and were from the North, which gets less rainfall than other regions. Finally, most of the farmers interviewed were over 40 years old; it is possible that their choice to practice farming is due to their age and the physical hardships of working in the pits.

Table 3. Sociodemographic characteristics of the sample. Source: Fieldwork (2017).

\begin{tabular}{|c|c|c|c|c|c|c|c|}
\hline \multirow[b]{3}{*}{ Variables } & & \multicolumn{4}{|c|}{ Artisanal Gold Mining Sites } & & \\
\hline & & \multicolumn{2}{|c|}{ Diosso } & \multicolumn{2}{|c|}{ Siguinoguin } & \multicolumn{2}{|c|}{ Zincko } \\
\hline & & $\begin{array}{c}\text { Mining } \\
\text { Area }\end{array}$ & $\begin{array}{c}\text { Non } \\
\text {-Mining } \\
\text { Area }\end{array}$ & $\begin{array}{c}\text { Mining } \\
\text { Area }\end{array}$ & $\begin{array}{c}\text { Non } \\
\text {-Mining } \\
\text { Area }\end{array}$ & $\begin{array}{c}\text { Mining } \\
\text { Area }\end{array}$ & $\begin{array}{c}\text { Non } \\
\text {-Mining } \\
\text { Area }\end{array}$ \\
\hline \multirow{5}{*}{ Age (in \%) } & $<18$ & 0.0 & 0.0 & 0.0 & 0.0 & 5.0 & 0.0 \\
\hline & $18-30$ & 23.1 & 0.0 & 31.8 & 0.0 & 52.5 & 0.0 \\
\hline & $31-40$ & 30.8 & 0.0 & 43.2 & 30.0 & 20.0 & 12.5 \\
\hline & $41-50$ & 33.3 & 38.5 & 9.1 & 30.0 & 15.0 & 12.5 \\
\hline & $>50$ & 12.8 & 61.5 & 15.9 & 40.0 & 7.50 & 75.0 \\
\hline \multirow{2}{*}{ Gender (in \%) } & Male & 94.9 & 100.0 & 84.1 & 100 & 82.5 & 62.5 \\
\hline & Female & 5.1 & 0.00 & 15.9 & 0.0 & 17.5 & 37.5 \\
\hline \multirow{4}{*}{ Household size (in \%) } & $1-3$ & 15.4 & 0.0 & 27.3 & 0.0 & 22.5 & 0.0 \\
\hline & $4-6$ & 33.3 & 7.7 & 38.6 & 0.0 & 42.5 & 0.0 \\
\hline & $7-10$ & 38.5 & 92.3 & 15.9 & 20.0 & 17.5 & 12.5 \\
\hline & $>10$ & 12.8 & 0.0 & 18.2 & 80.0 & 17.5 & 87.5 \\
\hline \multirow{3}{*}{ Education (in \%) } & None & 87.2 & 100 & 65.9 & 100 & 82.5 & 75.0 \\
\hline & Primary & 10.3 & 0.0 & 13.6 & 0.0 & 10.0 & 25.0 \\
\hline & Secondary & 2.6 & 0.0 & 20.5 & 0.0 & 7.5 & 0.0 \\
\hline \multirow{3}{*}{ Ethnicity (in \%) } & Mossi & 74.4 & 46.1 & 79.5 & 100 & 80.0 & 100 \\
\hline & Gourmantche & 10.3 & 0.0 & 11.4 & 0.0 & 0.0 & 0.0 \\
\hline & Other ethnicities & 15.4 & 53.8 & 9.1 & 0.0 & 20.0 & 0.0 \\
\hline \multirow{4}{*}{ Origin (in \%) } & North & 64.1 & 38.5 & 59.1 & 0.0 & 87.5 & 100 \\
\hline & East & 15.4 & 7.7 & 15.9 & 0.0 & 2.5 & 0.0 \\
\hline & South & 5.1 & 53.8 & 2.3 & 0.0 & 0.0 & 0.0 \\
\hline & Other regions & 12.8 & 0.0 & 18.2 & 100 & 0.0 & 0.0 \\
\hline
\end{tabular}




\subsection{Action Arena}

\subsubsection{Working Rules, Positions and Participants}

Boundary Rules

The literature on the boundary rules reveals that, once a mining site is declared, it works on a "first come, first serve" basis $[3,34,36]$. Following this stage, some fees are paid if one wants to obtain a plot for artisanal mining purposes: USD 7.5-10 paid per workplace on the camps of Lilila Goren and Kampti in Burkina Faso $[41,53,56]$. Our respondents in the three study areas have indicated that, once a mining camp is established, it attracts miners who migrate to the area from other parts of the country and settle down spontaneously. When the mining site is fully operating, the new arrivals negotiate with local landowners or customary authorities (i.e., village chief and representatives) regarding plot access. The chief shall ensure that the tradition is perpetuated and that the community is united. Thus, he participates in conflict resolutions and discusses various matters related to the village.The land allocation process varies though from one site to another. For instance, in Diosso, miners have three options for acquiring new plots. The first option is to take over a pit from an owner who is looking to transfer due to a lack of financial resources. Another possibility is to simply begin digging on the camp site's main gold-bearing vein. Thirdly, miners can try to reach an agreement on land access with local customary authorities. Once they have established themselves on a plot, miners must report their land claims to representatives of the artisanal miners' union or to customary authorities. The miners' union known as "Syndicat burkinabè des Orpailleurs Artisanaux et Traditionnels (SYNORARTRAB)" (Union of Artisanal and Traditional miners of Burkina) was created in 2008 to manage the difficulties and challenges that the sector is facing, more specifically the fact that the holders of the AAM were putting pressure on miners regarding purchase of their gold [69]. The latter groups will use the claims to resolve any property disputes among miners and other stakeholders. Conversely, in Siguinoguin, landowners allocate plots but also charge a compensation fee ranging between USD 20 and USD 30 because the mining site was established on former cropland. Miners in Siguinoguin are required to compensate landowners with a portion of the gold they extract from their pit. In Zincko, they must inform customary authorities before beginning work. The latter arrange an agreement between miners and potential landowners if necessary. From these observations, what appears is that the structure of the site depends on whether it is ruled by a landowner, customary authorities or a balanced power. It seems to be a continuum of rigidity ranging from balanced power to landowners. The more you approach a system of balanced power, the less rigid is the governance while the more you approach the landowners type of governance, the less rigid you become.

\section{Position Rules}

Regarding the work organization in mine pits, literature reported that working teams size is estimated at 30 people or more and that there is an individual known as patron in French who is responsible for covering all work-related expenses, a team leader [3,9,34,41,49,55]. In Zincko and Siguinoguin, between two and 20 people work in each pit. In Diosso, however, the teams are much larger, usually consisting of 20 to 70 workers. Diosso has a greater number of workers per pit because it is more crowded than the other two mining camps. However, at all three locations, pit owners known as patron in French are responsible for covering all work-related expenses, confirming Werthmann [9]. This includes providing workers with food, water, cigarettes, coffee, machinery and medical care. Owners usually do not enter the pit and are not always present during operations. Instead, they designate someone as the team leader (chef de groupe) who is put in charge of daily activities. A pit might have several team leaders, depending on the number of workers. One leader oversees the day shift (6:00 a.m.-6:00 p.m.), while another is responsible for the night shift (6:00 p.m.-6:00 a.m.). The team leader helps with digging and decides how many people enter the pit. In addition, he reports to the pit owner any problems such lack of materials, work-related illnesses and accidents. Gold diggers are divided into two work categories. The first group is made up of experienced diggers, while 
inexperienced newcomers form the second group. New diggers are often the most vulnerable team members because they work underground where they can be injured or killed by collapsing shafts. On the other hand, it is easy for newcomers to move into the more experienced group of diggers if they can prove their merit. Even though there seems to be a hierarchy in this organization, moving from one position to another is flexible and just depends on how much luck each individual may have in finding gold. On the basis of these facts, organization of work teams is similar regardless of the size of the mining pits, or the governing structures. This organization will only differ with the other teams working on mining camps doing panning, cyanide handling.

Table 4 illustrates the percentage of miners in each labor category. In Diosso, the largest mining camp, more than $50 \%$ of respondents were pit owners. Members of this group were more available for interviews than diggers, which explains their overrepresentation in the sample. This may be due to the fact that pits are deeper in Diosso than elsewhere. Thus, the work is more intense: most of the time, diggers are either working in the pits or resting. Siguinoguin was the only site where we came across a cyanide applicator, owing to the proximity of a cyanide processing center close to the camp. We also identified a dynamite handler in Siguinoguin. The individual was not a permanent member of any team, but owners would request his services if a pit was deeper than $10 \mathrm{~m}$. At Zincko, a large percentage of laborers worked as winnowers, using large plastic bowls to sieve through soil and retrieve gold nuggets. This feature comes from the spatial organization of the mine that include areas allocated to panning.

Table 4. Percentage breakdown of workers according to job category. Source: Fieldwork (2017).

\begin{tabular}{lccc}
\hline \multirow{2}{*}{ Positions } & \multicolumn{3}{c}{ Artisanal Gold Mining Sites } \\
\cline { 2 - 4 } & Diosso & Siguinoguin & Zincko \\
\hline Diggers (\%) & 15.4 & 29.5 & 30.0 \\
Team leaders (\%) & 10.2 & 4.5 & 7.5 \\
Guards (\%) & 0.0 & 2.3 & 17.5 \\
Supervisors (\%) & 12.8 & 2.3 & 17.5 \\
Dynamite handlers (\%) & 0.0 & 2.3 & 0.0 \\
Pit owners (\%) & 53.8 & 29.5 & 25.0 \\
Warehouse owners (\%) & 0.0 & 13.6 & 2.5 \\
Cyanide applicators (\%) & 0.0 & 2.3 & 0.0 \\
Buyers and sellers (\%) & 0.0 & 9.1 & 2.5 \\
Mill owners/users (\%) & 2.6 & 2.3 & 2.5 \\
Winnowers (\%) & 5.1 & 2.3 & 30.0 \\
\hline
\end{tabular}

Scope Rules

Scholars in the field have mentioned the importance of rituals undertaken by indigenous communities living in villages where artisanal mining is practised $[11,36,46,53,57,70]$. Rules regarding the terms of the use for artisanal gold are established orally. These rules specify what miners must agree to abide before they can begin working. For instance, every mining camp enforced a rule that women and children were not allowed in the tunnels. In terms of land allocation, at Siguinoguin, plots are issued for a fee. By contrast, landowners and customary authorities in Diosso and Zincko freely distribute them; in exchange, pit owners agree to hand over a portion of their earnings. At each of the three mining sites, Friday is a day off due to the belief that accidents are more likely to occur on that day. In addition, pit owners, notably in Diosso, offer livestock to customary officials that would be used for sacrifices at the indigenous village ancestor shrines in the hopes that they will bless them with more gold. Most miners do believe that gold is a supernatural element. As such, some rituals have to be made by the indigenous communities during the process of appropriating it as indicated in Werthmann [36], Werthmann [11], Mégret [53], Luning [57] and Lentz [70] in order to get the favor of the gods. However, evidence showed that, in some cases, the gifts given by the gold diggers for 
sacrifices are not used for that purposes; then, the gods are not soothed causing various accidents, deaths and conflicts in the communities as also noted in [11,53].

Choice Rules

Concerning the choice rule, not much has been said in the literature review. Our investigation indicated that work in the pits is usually monitored by team leaders, guards and supervisors depending on the stage of the pits. In Diosso, some pit owners use four people to oversee the work: one team leader is present in the mine hole, another is placed outside and two monitors supervise the overall work. A guard is not required during the initial stages of digging when gold has not yet been found. However, once gold begins to appear, the pit owner will choose to hire someone who is trustworthy as a guard from within the team or will turn to an outside person. The guard helps protect the mine, especially at night when gold thieves (topomal) are active. Even though there seems to be various ways of controlling over gold, materials and men, they still look inefficient because either pit owners and supervisors or guards may collude and get away with some of the gold removed from the pits.

Aggregation Rules

This aspect of the rules established on mining camps have not been fully discussed in the literature Team leaders generally decide whether someone can be absent themselves after discussing the matter with the pit owner and other workers. The leaders tend to make the decision since they are frequently present on site and know how to manage a potential worker absence. In a few cases, though, the pit owner is the one who decides after informing the other team members. Respondents acknowledge that it is rare for a person to be removed from the team but that it could occur if someone was not working enough, was being disobedient or was acting violently towards co-workers. Before doing so, team members would try to encourage the person to change his behavior. However, if the intervention proved unsuccessful, the individual would be forced to leave the group. These rules look to work well on all the study areas regardless of the size, the dominant governing structure or the origin of the indigenous communities.

Information Rules

The results of our fieldwork indicate that artisanal miners exchange information regarding established rules. For instance, all surveyed miners were aware that mining is prohibited during the rainy season because of the risk of tunnels collapsing. They were also aware that children are not allowed in the pits. However, some workers, especially diggers, were not always familiar with the plot allocation process or how landowners were remunerated. It is unclear whether this information was purposely hidden or not from certain workers. Furthermore, during interviews, miners were often reluctant to give information on the number of injuries and deaths that had occurred for fear of being reported to the government.

Payoff Rules

Of the literature discussing profit sharing in artisanal mining, many have pointed out half proportion to pit owners and the other half to the workers [3,41]. In our case, pit owners reported that operational costs depend on the depth of the pit. In Diosso, pits are typically $140 \mathrm{~m}$ deep and the cost of running one ranges from USD 30,000 to USD 60,000. Thus, clearly the depth of the pits impacts the related expenses because of the extra costs incurred by human capital and machinery. Given the average salary in Burkina Faso, this investment is huge; hence, in order to cope with such investments, pit owners will either be borrowing or sharing cost among others. In addition, a major part of pit owners were former entrepreneurs and saved enough money before taking up artisanal mining. By contrast, in Siguinoguin and Zincko, mining holes are less than $50 \mathrm{~m}$ deep and costs vary between USD 10,000 and USD 20,000 in line with the case of a mining camp in Kampti depicted by Mégret [53]. Even though mining pits have similar sizes in the latter two locations, in Siguinoguin, pit owners secure their pits by covering the inside with concrete in order to impede any collapse. Then, 
there is are additional financial burdens for purchasing cement and moulds. This practise proves to be safer for the diggers of Siguinoguin and must be encouraged in all mining camps of the country. Artisanal miners in all the mining camps use one of two methods for sharing revenues known as magoure or dessort as stated by Mégret [53] after landowners and customary authorities (i.e., village chief) have been paid. The first system allocates half of the gold ore to the pit owner and the other half is given to the workers. Subsequently, the ore will be processed to extract gold dust, although the amount that will be retrieved is unknown beforehand. Under the second method, one third of revenues are allocated to the pit owner to cover expenses, one third is shared equally among the workers and the pit owner takes the remaining third as profit. There is no sharing-profit specific to one location because it all depends on the prior agreement among pit owners, landowners, customary authorities and laborers.

\subsubsection{Outcomes}

Depending on whether pit miners are lucky or not, numerous outcomes may be achieved:

\section{- Outcome 1: Gold is discovered}

Certain factors determine whether gold is found. For instance, to avoid project delays, there must be a certain level of cohesion among group members. Once gold is discovered, an owner's financial obligations will determine who benefits from it. Pit owners sometimes lend money to each other or to gold purchasers [68]. If an owner who borrows money discovers gold, the lender will obtain a share of the profits proportional to the amount invested, which is known as selection on gold mining camps. As pointed out by Mégret [71], this term may be used for profit sharing. For instance, if the lender invested half of the required amount, he will get half the profits. In some cases, even after gold has been discovered, the revenue generated is not enough to cover expenses and the pit owner can end up with significant debt. In some cases, miners find gold but are evicted by the government officials. For instance, in Diosso, $70 \%$ of the sample admitted that relations had been tense with government officials affiliated with the regime of Blaise Campaore that collapsed in 2014. Miners were forced to sell their gold for USD 25 per gram instead of the market value of USD 42. If they refused, police officers would beat them and collect their gold without compensation; in such cases, pit owners lost their entire investment. In both cases, the gold dust or nugget is eventually sold either in the camp to individual buyers/sellers or outside of the camp in which case miners may be robbed on their way and eventually lose their gold.

\section{- Outcome 2: No gold is discovered, loss of part or entire investment}

While many artisanal miners have prospered, others have lost all or part of their investment and some have even left the sector after incurring significant debts. Usually, this occurs when pits collapse and become too dangerous to work in or when an owner runs out of money.

\subsection{Performance}

According to the IAD framework, to assess the management of community-based resources three elements must be evaluated: productivity, sustainability and poverty reduction.

- Productivity: In the context of our study, productivity refers to the quantity of gold extracted from each mine site. As we mentioned previously, the informal nature of artisanal mining makes it difficult to accurately estimate this amount that is coherent with the statement of Heemskerk [6]. Surveyed workers, however, were asked if they believed finding gold depended on some specific criteria. They pointed out luck, hard work or financial resources. According to the results, most respondents $(60 \%)$ conceded that luck was the most important determinant of performance followed by work and financial resources (Table 5).

- Sustainability: Sustainability is usually measured through three different indicators namely economic, environmental and social [72]. Moreover, the same criteria can be used to evaluate the sustainability of artisanal mining $[19,73]$. This indicator will be discussed in Section 4.4. 
- Poverty reduction: The results of our fieldwork indicate that small-scale mining has had a positive impact on poverty alleviation. As Table 5 shows, at each camp visited, more than $90 \%$ of respondents agreed that mining had improved their economic situation. Miners reported having more money for things such as paying for school costs, building a house or buying a motorcycle. Studies in Burkina Faso and Mali have shown that such types of purchases are clear indicators of improvements in household welfare $[3,8,11,41,53]$. As we have noticed during the field visit, artisanal mining also creates positive spillover effects for neighboring villages (Kien near Diosso, Arba near Zincko for instance) as traditional homes made from mud and straw are replaced by ones with steel roofing. The same conclusions were drawn by Mégret [53] and Teschner [41].

Table 5. Determinants of performance according to the respondents. Source: Fieldwork (2017).

\begin{tabular}{lccc}
\hline \multirow{2}{*}{ Performance } & \multicolumn{3}{c}{ Artisanal Gold Mining Sites } \\
\cline { 2 - 4 } & Diosso & Siguinoguin & Zincko \\
\hline Luck & 71.8 & 88.6 & 90.0 \\
Financial resources & 7.7 & 4.5 & 0.0 \\
Work & 20.5 & 6.8 & 10.0 \\
\hline
\end{tabular}

As Table 6 shows, more than $90 \%$ of artisanal miners surveyed acknowledged that working in the pits had improved their welfare situation. The following outline summarizes the social, economic and environmental effects of artisanal mining in the three communities visited.

Table 6. The economic effects of artisanal mining according to respondents. Source: Fieldwork (2017).

\begin{tabular}{lcccc}
\hline \multirow{2}{*}{ Impacts } & \multicolumn{3}{c}{ Artisanal Gold Mining Sites } \\
\cline { 3 - 5 } & & Diosso & Siguinoguin & Zincko \\
\hline \multirow{2}{*}{ Reduce poverty } & Yes & 94.8 & 100 & 97.5 \\
& No & 5.1 & 0 & 2.5 \\
\hline \multirow{2}{*}{ Improve welfare conditions } & Yes & 94.8 & 100 & 97.5 \\
& No & 5.1 & 0 & 2.5 \\
\hline
\end{tabular}

\subsection{Sustainable Development Indicators}

\subsubsection{Social Indicators}

- Employment

All respondents agreed that artisanal mining had created employment opportunities for both local and migrants communities. For local communities, the establishment of a mining camp provide opportunities for people to be hired as laborers (diggers, crushers, mill operators...) on camps while women pursue petty trade as sale of food and water [9,11,53,71]. Furthermore, nearby farmers gain revenue by selling agricultural products. Other non-miner migrants hold commercial shops from clothing stores, to electronic and, most importantly, movie theaters that create a lively environment where miners may relax overnight similar to the findings of Mégret [71]. Finally, once in a while, when pit owners retrieve gold, they are so generous that they would give money to some lucky inhabitants.

- Health and safety

Several health and safety issues were reported on the sites. Dust from the pits was causing respiratory problems because workers did not have proper personal protective equipment; and injuries and deaths had occurred due to collapsing shafts as discussed by Werthmann [3], Jaques et al. [55]. Since there were no medical centers on site, miners resort to self-treatment by purchasing usually prohibited medications from medicine vendors. In line with 
Mégret [53] work in Kampti, miners on the study camps use some drugs and adulterated liquor in order to face the hardship of the work that eventually degrade their health condition.

\section{- $\quad$ Child labor}

Children are frequently seen on site during our field trip. Nevertheless, all respondents agree that they are prohibited to enter mining pits at less than 17 years of age. They generally cook for the miners (in which case they are called bantaris). These children do not come from the nearest villages and their origin is not always known by the pit owners. They will live on the camps and taken care of by the pit owners as any other laborer while doing the cook. Apart from these ones, children from the nearby villages would work on site daily, as ore crushers or sellers. This is opposed to the findings of the investigation conducted by Gueniat and White [64], which revealed that a great deal of gold smuggled through Togo towards Switzerland is extracted by children in extreme working conditions. It is important to note that the reliability of this research is limited as respondents may not admit to illegal activities.

- Relationships with local communities

In Diosso, customary authorities were not satisfied with the earnings that they were receiving from pit owners, and complained that mining was causing local prices to increase and polluting the drinking water. Furthermore, governance and politics were at stake in Diosso. In fact, as migration is sustained over time, at one point, the population of migrants (Mossi) is greater than that of the indigenous. Thus, during elections, migrants tend to vote for a migrant that would likely enact politics favourable to artisanal mining at the expense of the indigenous communities. In such context, indigenous communities contested the results leading to extreme violence between migrants and indigenous communities [74]. In Siguinoguin, relationships were tense between miners and the local population over nuisance issues, the death of livestock due to water contamination from the mine, destruction of trees among others [11,55]. Disputes are settled before elders and/or customary authorities. If no resolution is reached, the case is handed over to the police. In contrast, in Zincko, relations were harmonious since the miners hail from the local community. Basically, artisanal mining culturally dismantles the social patterns in rural areas. First, at a local level, land tenure arrangements in artisanal mining areas generate revenue for land owners. Then, local communities would be tempted to base their revenue only on this new source. As we know, this source is not sustained over time and that lead to structural implication for their offspring. Second, in some cases, due to the highest revenue earned by young miners, they do not abide by the customs which include respect for elders and willingness to pursue farming. Second, there is a risk of breaking up between former miners that had been successful and the newcomers that would fail due to a potential depletion of the resource.

\subsubsection{Economic Indicators}

- $\quad$ Revenue sharing with local communities

Pit owners reach informal agreements with customary authorities whereby they consent to hand over part of their revenues. In Diosso, pit owners give one tenth of their bags to customary authorities and in Zincko the same proportion of bags is delivered to the landowner. In Siguinoguin, pit owners also hand over one tenth of their bags, in addition to paying a plot issuance fee, which costs between USD 20 and USD 30 as reported by Werthmann [3]. Regarding the investment in local communities, our survey reveals that, in general, in the villages of Diosso, Zincko and Siguinoguin miners do not contribute to the local development of the village (i.e., contribute to build schools, hospitals and other infrastructure). However, the head of the miners' union has reported in September 2016 that the union has provided houses for teachers, ambulances, 14 water pumps, two water towers and 32 motorcycles to village representatives of the province of Bam [69]. 


\subsubsection{Environmental Indicators}

It is difficult to measure a resource's depletion rate. Nevertheless, respondents indicated that the quantity of gold was diminishing over time as miners dig deeper.

- Environment

Miners cut down trees and use them to prevent the pits from collapsing or to create a pulley system for lifting miners and materials as stated in Mégret [71] and Werthmann [3]. Sometimes, this destruction is a source of tensions between miners and local communities especially in the village of Siguinoguin. The same case is portrayed by Werthmann [11] as gold discovery in the village of Dimouan attracted many miners from around Burkina Faso that did not hesitate to cut some protected trees such as karite. Even though most actions of miners are not favourable for the environment, we have observed that the use of reusable bags to store gold ore, assemble houses or toilets; gathering places for worship or socialization are positive for sustainability. Adding to the destruction of trees is the fact that mine pits that are no longer useful are usually not filled in, which prevents the land from being converted back to agricultural use (in Diosso and Siguinoguin). We believe that finding ways to do so will considerable impede the negative environmental impacts of artisanal mining. For near-surface artisanal gold mining, pits can still be converted back to agriculture use (in Zincko). Thus far, the question that remains is whether industrial mining negative impacts are not greater than the artisanal mines impacts because many studies focus on the latter overlooking the former.

- Air, noise and water pollution

Small-scale mining uses mercury to amalgamate gold. The amalgam gives the gold a grayish color, which is removed through heating. However, the heat treatment process releases gases that are dangerous to human health. Dynamite is used at all three sites when pits reach $10 \mathrm{~m}$ deep and digging is too difficult as described by Mégret [71]. This creates noise pollution for residents of the surrounding areas. The quantity of water used to remove gold is small compared to what is collected from the underground during digging. This water is reused in several ways. First, miners use it to wash the gold ore. Second, they use it for baths. Sometimes, the water is just pumped out of the pits and spilled on the ground with no use. One might be tempted to ask why this water is not used for agricultural purposes. Water from the mines is often polluted since workers sometimes stay in the pits for several days and defecate in the open air. As a result, farmers often prefer not to use it for agricultural purposes (this was especially the case in Diosso). This is not solely the issue here as cyanide used by miners is carried by heavy rains from the camp to nearby areas, resulting in the death of livestock from water contamination. Such situation leads to dispute between miners and agropastoralist communities as mentioned in Jaques et al. [55]. One way of dealing with this waste water would be to organize some methods of treating it in order to deliver drinkable water for populations and usable water for agriculture.

\section{Discussion and Conclusions}

The aim of this paper is to discuss the different modes of governance that occur on non-industrial gold mining sites of Burkina Faso. Our results unsurprisingly indicate that informal rules governed the mining camp as pointed out, but several researchers in the case of Burkina and elsewhere $[3,11,34,36]$. However, it differs from the sites of Bantara and Gombeledougou in Burkina Faso investigated by Arnaldi di Balme and Lanzano [34]. In those communities, gold trading posts (comptoirs) dictated the rules around such things as plot allocation and gold resale conditions. They also differ from cases in Burkina Faso of mines run by individuals for personal profit with the consent of customary authorities and landowners $[8,11]$. In our specific cases, the artisanal mining camps work in a similar way: labor hierarchical organization featuring pit owners, team leaders, experienced diggers, guards inexperienced diggers, etc., the prohibition for women and children to enter the mining pits. However, at the bottom, modes of governance are diverse. 
First, in Diosso, the governance depends upon a stronger role played by the artisanal gold miners union, which becomes a legitimate authority. As the number of migrants from the Northern region of the commune increases, the indigenous customary authorities loses weight and legitimacy. As a result, customary authorities are no more capable of enjoying the benefits provided by their status of indigenous community. On the other hand, in Siguinoguin landowner and relatives, and police officers regulate the mining camp according to stricter rules. In Zincko, the autochtony is a strong capital as miners are from the indigenous community and allow customary authorities to govern the site peacefully (see Figure 2). Therefore, we can conclude that these types of governance vary along a continuum from a flexible to a rigid form of governance.

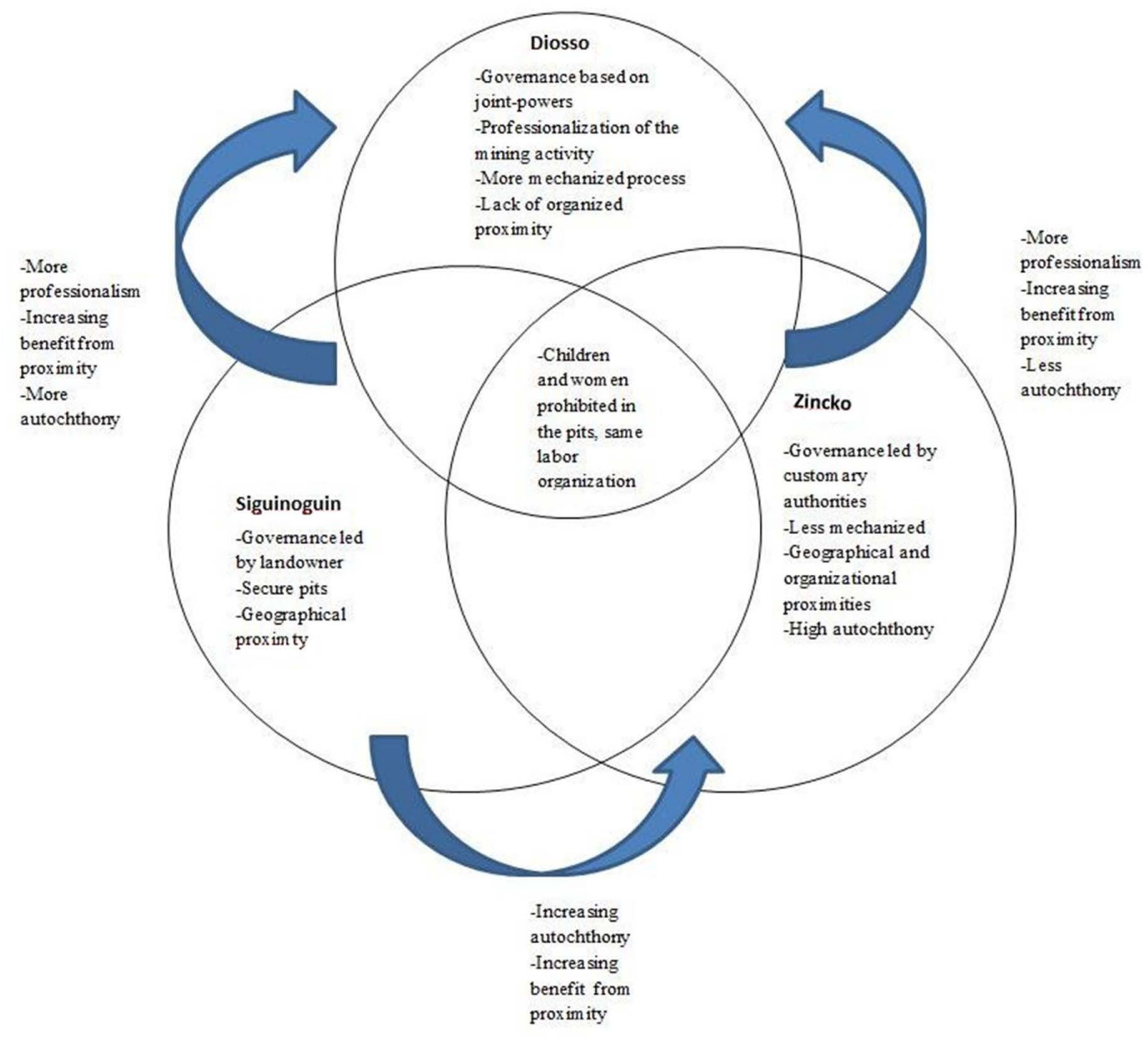

Figure 2. Representation of the different modes of governance.

Second, the conceptual framework allows us to discuss geographical proximity as a component of attributes of the physical world. However, it does not manage to give details on the different forms of relational proximity, which should be viewed as part of community's attributes, whereas these dimensions clearly structure the way governance is organized in the mining camps. In order to expand these two dimensions, we rely on the French school of proximity which provides possibilities to detail and enrich the definitions given to the attributes of the physical world and the attributes of the community highlighted by Ostrom's theory. The proximity in the perspective of the French school of proximity is a concept both spatial and relational that identifies two forms of proximity: geographical proximity and "organized" proximity (see $[8,75,76])$. Geographical proximity reflects the distance (in kilometers) between two actors weighted by the perception that individuals have of this distance in terms of time spent or transportation cost. When considering its role in coordinating individuals or organizations, geographic proximity may take two dimensions: temporary or permanent [76], which 
is the case of gold mining camps which are permanently occupied places, notably by the villagers but seasonally by some of the miners. It can also be sought when it is activated by the actors to foster coordination between them in case some have to bear the effects of an activity (noise, odors, unfair competition...) without being able to choose to move away from it. "Organized" proximity consists of two complementary approaches. The first is the logic of belonging that appears within same organization or network. Thanks to this logic of belonging, individuals interact with each other more easily. The second is the logic of similarity which designates a common system of representations, values and beliefs shared by a group of individuals. Geographical and organized proximities are connected. On one hand, geographical proximity can be effectively valued thanks to the relationships established in the context of organized proximity. On the other hand, there are various situations in which both types of proximity can be compensated. Thus, in case of territorial conflicts (for example when geographical proximity is unwelcome because it generates adverse effects for some actors), the development of organized proximities is a governance tool that brings stakeholders together.

Referring to the theory of proximity, we can assert that, although there is a lack of geographical proximity, the indigenous communities suffered from the presence of the mining camps (food price inflation, water shortage). However, they do tolerate them as they take full advantage of the commercial opportunities (sale of goods and services, employment) with their economic situation. Hence, there is a geographical proximity rather than organized proximity as both communities do not share same values or identities. In Siguinoguin, the local community suffered from this geographical proximity. Unlike the case of Diosso, the mining camp is not tolerated at all due to the direct impact of the chemicals used in gold processing (cyanide and mercury) that cause deaths of cattle and also pollute water. In such context, geographical proximity is rather unwelcome by the indigenous community. Conversely, in Zincko, the situation is different; even though there is a geographical proximity between the mining camp and the village, miners are fully tolerated mainly because they are part of the indigenous community, thus share logic of belonging and logic of similarity as illustrated by the school of proximity. Both geographical and organized proximity help maintain positive interactions among individuals. Basically, a general tendency can be derived from these various situations: more both geographical proximity and the autochtony increases less tensions will arise between the indigenous communities and the miners (see Figure 2). Hence, when moving from Diosso to Siguinoguin and then from Siguinoguin to Zincko, the geographical proximity and the rate of autochthony of miners creates different reactions from the indigenous communities. Here, it is also important to note that the directions indicated by the arrows illustrate that, naturally, a mining site tends to move from less to more professionalized and mechanized processes.

Third, regarding the rules information, in Diosso, because the police station is far from the mining camp and miners are migrants, the requirement that closes mining pits in the rainy season is not respected much. It tends to be respected in Siguinoguin as the police station is established in the mining camp. In Zincko, the high rate of miners' authocthony helps enforce this requirement as customary authorities care about their people and do not want to expose them to accidents and deaths while work conditions are unsafe. A general trend that comes out is that rules are respected in the presence of police station and there is a high rate of autochthony, while they will not be respected otherwise.

Fourth, our finding related to scope rules depends on the specific mining site. For example, an entrance fee is likely to be applied when the landowner plays a key role in the governance of the site (Siguinoguin). The access will be controlled when customary authorities rule (Siguinoguin) while it will be unrestricted in the presence of co-governance (Diosso). Then, rules related to access to mining camps varies as you move from a sole key player to various keys players on the mining camp. Additionally, differences in terms of pay off rules are underscored: in Diosso, pit owners seem to be financially better off than pit owners in Siguinoguin and Zincko. This outlines the fact that the higher the initial investment (and the richer the underground), the higher the revenues obtained from mining and pit owners would play a more influential role in governance matters. 
After examining the diverse dissimilarities between the different mining camps regarding the modes of governance, there is a need to oversee the non-industrial gold mining sector in Burkina Faso. Even though the government of Burkina Faso enacted a law in 2015 that would allow the creation of an agency to monitor artisanal gold mining known as Agence Nationale d'Encadrement des Exploitations Minieres Artisanales et Semi-mecanisees (National Agency for the Management of Artisanal and Semi-Mechanic Mining Exploitations), it is essential to discuss with all the stakeholders of the sector in order to integrate all in this approach. This initiative must come into force as soon as possible in order to limit environmental damage and work-related accidents and illnesses. Furthermore, the authorization for artisanal mining permits has to be reviewed since the field research has shown that only wealthy entrepreneurs can acquire such permits due to the complex procedure from the point of view of most miners who has no formal education, thus marginalizing miners working on the area under permits. In effect, the very informal nature of the rules may be due to the fact that most of these people can not read and it is therefore more judicious and effective to operate informally. It probably also means that any public action based on licenses or permits would have the effect of marginalizing a certain number of people who are unable to fill in the required documentation as experienced in most African countries. In such context, we would suggest to decentralize the management of the permits. For instance, a permanent worker that speaks the local languages would be appointed at the mining sites to manage the permits.

In a nutshell, this study will help promote and strengthen the social cohesion between local communities and migrants as this paper showed increasing conflicts occurring between migrants and local communities. In addition, it will help communities to take actions to protect the environment, as we have seen land destruction and pollutions on the mining camps. These actions include creating prohibited zones for people and livestock where cyanide and mercury are processed as well as rehabilitating degraded lands. This study will also encourage government to intervene in supporting agriculture by helping young miners to value their earnings in investing in small-scale agricultural production and regulate agricultural integration by easing land acquisition process for migrants.

Author Contributions: The first author L.O. designed the research, collected and analyzed data and wrote the paper. The second author, P.M., helped improve the writing skills of the paper and organize data according to the various conceptual frameworks. All authors read and approved the final manuscript.

Funding: : This research was funded by the Canadian Social Sciences and Humanities Research Council.

Conflicts of Interest: The authors declare no conflict of interest.

\section{References}

1. Labonne, B. Artisanal mining: An economic stepping stone for women. Nat. Resour. Forum 1996, 20, 117-122. [CrossRef]

2. Grätz, T. Mining Frontiers in Africa: Anthropological and Historical Perspectives. In Gold Mining in the Atakora Mountains in Benin: Exchange Relations in a Volatile Economic Field; Rüdiger Köppe Verlag: Köln, Germany, 2012; pp. 97-118.

3. Werthmann, K. The drawbacks of privatization: Artisanal gold mining in Burkina Faso 1986-2016. Resour. Policy 2017, 52, 418-426. [CrossRef]

4. Jennings, N. Social and Labour Issues in Small-Scale Mines: Report for Discussion at the Tripartite Meeting on Social and Labour Issues in Small-Scale Mines, Geneva, 1999; International Labour Organization: Geneva, Switzerland, 1999.

5. World Bank. Mining Together: Large-Scale Mining Meets Artisanal Mining-A Guide for Action; Technical Report; World Bank: Washington, DC, USA, 2009.

6. Heemskerk, M. Collecting data in artisanal and small-scale mining communities: Measuring progress towards more sustainable livelihoods. In Natural Resources Forum; Wiley Online Libary: Oxford, UK, 2005; Volume 29, pp. 82-87.

7. Van Bockstael, S. The Persistence of Informality: Perspectives on the Future of Artisanal Mining in Liberia. Futures 2014, 62, 10-20. [CrossRef] 
8. Sangaré, O.; Mundler, P.; Ouedraogo, L. Institutions informelles et gouvernance de proximité dans l'orpaillage artisanal. Un cas d'étude au Burkina Faso. Revue Gouvernance 2016, 13, 53-73. [CrossRef]

9. Werthmann, K. Translocality: The study of globalising processes from a southern perspective. In 'Following the Hills': Gold Mining Camps as Heterotopias; Brill: Leiden, The Netherlands, 2010; pp. 111-132.

10. Veiga, M.M.; Scoble, M.; McAllister, M.L. Mining with communities. In Natural Resources Forum; Wiley Online Library: Oxford, UK, 2001; Volume 25, pp. 191-202.

11. Werthmann, K. Histoire du Peuplement Et Relations Interethniques au Burkina Faso. In Ils Sont Venus Comme une Nuée de Sauterelles-Chercheurs d'or au Burkina Faso; Karthala: Paris, France, 2003; Volume 97, p. 110.

12. Banchirigah, S. How reforms have fuelled the expansion of artisanal mining? Evidence from sub-Saharan Africa. Resour. Policy 2006, 31, 164-171. [CrossRef]

13. Kitula, A.G. The environmental and socio-economics impacts of mining on local livelihoods in Tanzania: A case of Geita District. J. Clean. Prod. 2006, 14, 405-414. [CrossRef]

14. Maconnachie, R.; Binns, T. Farming miners or mining farmers: Diamond mining and rural development in post-conflict Sierra Leone. J. Rural Stud. 2007, 23, 367-380. [CrossRef]

15. Garforth, C.; Hilson, G. Everyone is now concentrating on the mining: Drivers and implications of rural economic transition in the Eastern Region of Ghana. J. Dev. Stud. 2013, 49, 348-364.

16. Pijpers, R. Crops and Carats: Exploring the Interconnectedness of Mining and Agriculture in sub-Saharan Africa. Futures 2014, 62, 32-39. [CrossRef]

17. Hinton, J.; Veiga, M.M.; Beinhoff, C. Women and Artisanal Mining: Gender Roles and the Road Ahead. In The Socio-Economic Impacts of Artisanal and Small-Scale Mining in Developing Countries; AA Balkema, Sweets Publishers: Hurst, TX, USA, 2003.

18. Telmer, K.H.; Veiga, M.M. World emissions of mercury from artisanal and small-scale gold mining. In Mercury Fate and Transport in the Global Atmosphere; Springer: Boston, MA, USA, 2009; pp. 131-172.

19. Azapagic, A. Developing a framework for sustainable development indicators for the mining and minerals industry. J. Clean. Prod. 2004, 12, 630-662. [CrossRef]

20. Tschakert, P.; Singha, K. Contaminated Identities: Mercury and Marginalization in Ghana's Artisanal Mining Sector. Geoforum 2007, 38, 1304-1321. [CrossRef]

21. Hardin, G. The tragedy of the commons. Science 1968, 162, 1243-1248. [PubMed]

22. Ostrom, E. Governing the Commons; Cambridge University Press: Cambridge, UK, 1990.

23. Ostrom, E.; Gardner, R.; Walker, J. Rules, Games, and Common Pool Resources; The University of Michigan Press: Ann Arbor, MI, USA, 1994.

24. Hayes, T.M. Parks, people, and forest protection: An institutional assessment of the effectiveness of protected areas. World Dev. 2006, 34, 2064-2075. [CrossRef]

25. Coleman, E.A. Institutional factors affecting biophysical outcomes in forest management. J. Policy Anal. Manag. 2009, 28, 122-146. [CrossRef]

26. Imperial, M.T.; Yandle, T. Taking institutions seriously: Using the IAD framework to analyze fisheries policy. Soc. Nat. Resour. 2005, 18, 493-509. [CrossRef]

27. Fisher, E. Artisanal Gold Mining at the Margins of Mineral Resource Governance: A Case from Tanzania. Dev. S. Afr. 2008, 25, 199-213. [CrossRef]

28. Ellis, F. Household strategies and rural livelihood diversification. J. Dev. Stud. 1998, 35, 1-38. [CrossRef]

29. Hilson, G. Small scale mining, poverty and economic development in SSA: An overview. Resour. Policy 2009, 34, 1-5. [CrossRef]

30. Maclin, B.J.; Kelly, J.T.; Perks, R.; Vinck, P.; Pham, P. Moving to the mines: Motivations of men and women for migration to artisanal and small-scale mining sites in Eastern Democratic Republic of the Congo. Resour. Policy 2017, 51, 115-122. [CrossRef]

31. Bryceson, D.F.; Jønsson, J.B. Gold digging careers in Rural East Africa: Small-Scale Miners' Livelihood Choices. World Dev. 2010, 38, 379-392. [CrossRef]

32. Hilson, G. 'Once a miner, always a miner': Poverty and livelihood diversification in Akwatia, Ghana. J. Rural Stud. 2010, 26, 296-307. [CrossRef]

33. Werthmann, K. Working in a Boom-Town: Female Perspectives on Gold-Mining in Burkina Faso. Resour. Policy 2009, 34, 18-23. [CrossRef]

34. Arnaldi di Balme, L.; Lanzano, C. Gouverner l'éphémére. étude sur l'organisation technique et politique de deux sites d'orpaillage Bantara et Gombélèdougou, Burkina Faso. Étude Récit 2014, 37, 71. 
35. Noetsaller, R. Small Scale Mining: A Review of the Issues; World Bank: Washington, DC, USA, 1987.

36. Werthmann, K. Cowries, Gold and 'Bitter money'. Gold-mining and notions of ill-gotten wealth in Burkina Faso. Paideuma 2003, 49, 105-124.

37. Werthmann, K. Gold Mining and Jula Influence in Precolonial Southern Burkina Faso. J. Afr. Hist. 2007, 48, 395-414. [CrossRef]

38. Dondeyne, S.; Ndunguru, E. Artisanal mining in Central Mozambique: Policy and environmental issues of concern. Resour. Policy 2009, 34, 45-50. [CrossRef]

39. Banchirigah, S.; Hilson, G. De-agrarianization, re-agrarianization and local economic development: Re-orienting livelihoods in African artisanal mining communities. Policy Sci. 2010, 43, 157-180. [CrossRef]

40. Hilson, G.; Okoh, G. Poverty and livelihood diversification: Exploring the linkages between smallholder farming and artisanal mining. J. Int. Dev. 2011, 23, 1100-1114.

41. Teschner, B.A. “Orpaillage Pays for Everything": How Artisanal Mining Supported Rural Institutions Following Mali's Coup d'état. Futures 2014, 62, 140-150. [CrossRef]

42. Hilson, G. Land use competition between small- and large scale miners: A case study of Ghana. Land Use Policy 2002, 19, 149-156. [CrossRef]

43. Nyame, F.; Blocher, J. Influence of land tenure practises on artisanal mining activity in Ghana. Resour. Policy 2010, 35, 47-53. [CrossRef]

44. Bashwira, M.R.; Cuvelier, J.; Hilhorst, D.; van der Haar, G. Not only a man's world: Women's involvement in artisanal mining in Eastern Democratic Republic of Congo. Resour. Policy 2014, 40, 109-116. [CrossRef]

45. Hilson, G.; Osei, L. Tackling Youth Unemployment in sub-Saharan Africa: Is There a Role for Artisanal and Small-Scale Mining? Futures 2014, 62, 83-94. [CrossRef]

46. Luning, S. World of debts: Interdisciplinary perspectives on gold mining in West Africa. In Beyond the Pale of Property: Gold Miners Meddling with Mountains in Burkina Faso; Rozenberg Publishers: Amsterdam, The Netherlands, 2010; pp. 25-48.

47. Werthmann, K. The president of gold diggers: Sources of power in a gold mine in Burkina Faso. Ethnos 2003, 68, 95-111. [CrossRef]

48. Sangaré, O. Rôle de L'orpaillage Dans le Système D’activités des Ménages en Milieu Agricole: Cas de la Commune Rurale de Gbomblora Dans la Région Sud-Ouest du Burkina Faso. Master's Thesis, Université Laval, Québec, QC, Canada, 2016.

49. Di Balme, L.A.; Lanzano, C. Entrepreneurs de la frontière: Le role des comptoirs prives dans les sites d'extraction artisanale de l'or au Burkina Faso. Polit. Afr. 2013, 3, 27-49. [CrossRef]

50. Kiethega, J.B. L'or de la Volta Noire; Centre de Recherches Africaines: Paris, France, 1983.

51. Bantenga, M. L'or des Régions de Poura et de Gaoua: Les Vicissitudes de L'exploitation Coloniale, 1925-1960. Int. J. Afr. Hist. Stud. 1995, 28, 563-576.

52. Amutabi, M.; Lutta-Mukhebi, M. Gender and Mining in Kenya: The Case of the Mukibira Mines in the Vihiga District. Jenda J. Cult. Afr. Women's Stud. 2001, 1, 1-23.

53. Mégret, Q. Déjouer la mort en Afrique. In L'or "mort ou vif " L'orpaillage en pays Lobi Burkinabé; L'Harmattan: Paris, France, 2008; pp. 15-41.

54. Campbell, B.; Belem, G.; Coulibaly, V.N. Poverty Reduction in Africa: On Whose Development Agenda? Lessons from Cotton and Gold Production in Mali and Burkina Faso; Research Paper; Oxfam America: Boston, MA, USA, 2007.

55. Jaques, E.; Zida, B.; Billa, M.; Greffié, C.; Thomassin, J.F. Small-Scale Mining, Rural Subsistence and Poverty in West Africa; Practical Action Publishing: Rugby, UK, 2006.

56. Luning, S. Small scale mining, rural subsistence and poverty in West Africa. In Artisanal Gold Mining in Burkina Faso: Permits, Poverty and Perceptions of the Poor in Sanmatenga, the 'Land of Gold'; Practical Action Publisher: Rugby, UK, 2006; pp. 135-148.

57. Luning, S. Traditions on the Move. Essays in Honor of Jarich Oosten. In Gold in Burkina Faso: A Wealth of Poison and Promise; Rozenberg: Amsterdam, Netherlands, 2009; pp. 117-136.

58. Luning, S. Dilemmas Of Development. In Gold Mining in Sanmatenga, Burkina Faso: Governing Sites, Appropriating Wealth; African Studies Center: The Netherlands, 2008; pp. 189-205.

59. Campbell, B.K.; Loxley, J. Structural Adjustment in Africa; MacMillan: London, UK, 1989.

60. Campbell, B.; Prémont, M.C. What is behind the search for social acceptability of mining projects? Political economy and legal perspectives on Canadian mineral extraction. Min. Econ. 2017, 30, 171-180. [CrossRef] 
61. Gueye, D. Small-Scale Mining in Burkina Faso; International Institute for Environment and Development: London, UK, 2001.

62. Bossom, R.; Varon, B. L'industrie Minière Dans le Tiers Monde; Banque Mondiale: Washington, DC, USA, 1977.

63. Campbell, B. Mining in Africa: Regulation and Development; IDRC: Ottawa, ON, Canada, 2009.

64. Gueniat, M.; White, N. A Golden Racket: The True Source of Switzerland's "Togolese" Gold; Technical Report; Berne Declaration: Zurich, Switzerland, 2015.

65. Saldarriaga-Isaza, A.; Villegas-Palacio, C.; Arango, S. The public good dilemma of a non-renewable common resource: A look at the facts of artisanal gold mining. Resour. Policy 2013, 38, 224-232. [CrossRef]

66. Denzin, N.K.; Lincoln, Y.S. Strategies of Qualitative Inquiry; Sage Publications Inc.: Thousand Oaks, CA, USA, 1998.

67. Saldana, J. Fundamentals of Qualitative Research; Oxford University Press: Oxford, UK, 2011.

68. Grãtz, T. Les Frontières de L'orpaillage en Afrique Occidentale. Autrepart 2004, 2, 135-150. [CrossRef]

69. BOB. Mines au Burkina: Le Syndicat des Orpailleurs Artisanaux Souhaite une "RéElle Politique D'Encadrement" du Secteur (ITW, Responsable). Available online: http://news.aouaga.com/h/102493.html (accessed on 30 November 2017).

70. Lentz, C. Land, Mobility, and Belonging in West Africa; Indiana University Press: Bloomington, IN, USA, 2013.

71. Mégret, Q. Afriques au figuré: Images migrantes. In Comment Faire "Son Cinema" Dans un Camp Minier du Sud Ouest Burkinabé; Archives Contemporaines: Paris, France, 2013; pp. 163-188.

72. Brundtland, G.H. Report of the World Commission on Environment and Development: "Our Common Future"; Technical Report; United Nations: New York, NY, USA, 1987.

73. Kumah, A. Sustainability and gold mining in the developing world. J. Clean. Prod. 2006, 14, $315-323$. [CrossRef]

74. Danoaga, D. Election du Maire, 2 Morts a Karangasso-Vigue, Sidwaya. Available online: http://www. sidwaya.bf/m-11947-election-du-maire-2-morts-a-karangasso-vigue-.html (accessed on 26 December 2017).

75. Shaw, A.T.; Gilly, J.P. On the analytical dimension of proximity dynamics. Reg. Stud. 2000, 34, 169-180. [CrossRef]

76. Torre, A. Jalons pour une analyse dynamique des Proximités. Revue d'Économie Régionale Urbaine 2010, 3, 409-437. [CrossRef]

(C) 2019 by the authors. Licensee MDPI, Basel, Switzerland. This article is an open access article distributed under the terms and conditions of the Creative Commons Attribution (CC BY) license (http://creativecommons.org/licenses/by/4.0/). 